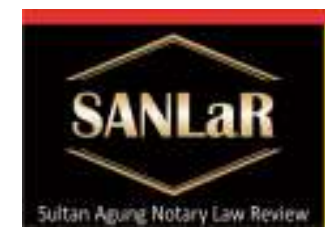

Volume 3 No. 3, September 2021
Sultan Aqung

Notary Law Review

The Urgence of... (Muhammad Maulana Kevin Rizaldi, Anis Mashdurohatun \& Maryanto)

\title{
The Urgence of Notary Deed for Organs Transplantation in Framework of Preventing Human Organs Transaction
}

\author{
Muhammad Maulana Kevin Rizaldi ${ }^{*}$, Anis Mashdurohatun ${ }^{* *}$ and Maryanto ${ }^{* * *}$ ) \\ *) Faculty of Law, Universitas Islam Sultan Agung (UNISSULA) Semarang, E-mail: \\ mmkevin2021@gmail.com
}

${ }^{* *}$ Faculty of Law, Universitas Islam Sultan Agung (UNISSULA) Semarang, Email: anism@unissula.ac.id $\left.{ }^{* * *}\right)$ Faculty of Law, Universitas Islam Sultan Agung (UNISSULA) Semarang, Email:
maryanto@unissula.ac.id

Abstract. Trafficking in human organs is a threat and also a crime for humanity. Crimes against humanity, the United Nations then formulated the practice of trafficking in human organs which was carried out with illegal means and purposes as part of a transnational crime. The regulation on organ transplantation in Indonesia is regulated in Act No. 36 of 2009 concerning Organ Transplantation. To ensure legal certainty in organ transplantation, both donors and recipients will submit a written statement not to buy organs from a prospective donor or enter into a special agreement with a prospective donor, which is stated in the form of a notary deed or a written statement ratified by a notary. The research objective is to analyze the urgency of the notarial deed of organ transplantation in the context of preventing the sale and purchase of human organs based on the Minister of Health Regulation No. 38 of 2016, the obstacles that arise in the making of a notary deed, the formulation of a notary deed in the implementation of organ or human tissue transplantation. This research is included in empirical juridical research with descriptive analysis research specifications. Sources of data used are primary data and secondary data. Data collection was carried out by field research and library research, then after the data was analyzed, conclusions were drawn using inductive thinking methods. Based on the results of the study found From the positive law, namely Permenkes No. 38 of 2016 and Islamic law, in organ transplantation it is known that there is a condition that there is no sale and purchase of organs, there is no special agreement that provides benefits to the donor and is carried out with a notarial deed in the form of an agreement or written statement under the hand that legalized or waarmerking. Currently, there are no technical or procedural 
obstacles in making a notarial deed of organ transplantation in the context of preventing the sale and purchase of human organs. The formulation of a notarial deed in the implementation of human organ or tissue transplants based on the Minister of Health Regulation No. 38 of 2016 is based on the legal arrangement regarding authentic deeds, namely Article 1868 BW.

Keywords: Notary; Deed; Organ; Transplantation; Transaction.

\section{Introduction}

Health services basically aim to carry out prevention and treatment of a disease, including medical services based on the individual relationship between doctors and patients who need healing for their illness. ${ }^{1} \mathrm{~A}$ doctor is a party who has expertise in the medical field or is considered to have the ability and expertise to perform medical actions. While the patient is a sick person who is ignorant of the disease he is suffering from and entrusts himself to be treated and cured by a doctor. Therefore, doctors in carrying out their duties as medical personnel are obliged to provide the best medical services for patients, as well as develop the treatment of a disease. ${ }^{2}$.

Indonesia is expected to continue to be open to the development of science and technology related to health. In addition to being open, of course, existing science and technology should continue to be improved from various aspects so that they can meet the community's need for health and achieve prosperity. One of the medical actions which is an advancement of the medical world and is very demanding on the practical skills of a doctor's anatomy but is very vulnerable to the rule of law is the transplantation of tools and organs of the human body. ${ }^{3}$

When the success rate of organ transplantation increases, the demand for organs and tissues of the human body that will be used as donors will also increase, at the beginning of the development of human organ transplantation technology the source of donors comes from the family alone, but it can also begin to grow day by day to the circle which is broader, so that if the patient does not get a donor from the family, the patient is forced to find someone else who wants to donate his organ. ${ }^{4}$ The practice of donating and transplanting

\footnotetext{
${ }^{1}$ Bander Jonathan Nasution, Hukum Kesehatan: Pertanggungjawaban Dokter, (Jakarta: Rineka Cipta, 2005), p.11.

2 Ibid, p.12.

${ }^{3}$ Veronika Komalawati, Peran Inform Consent Dalam Transaksi Terapiutik (Persetujuan Dalam Hubungan Dokter dan Pasien) Suatu Tinjauan Yuridis, (Bandung: Citraa Aditya Bakti, 2002), p.140141.

${ }^{4}$ Ibid, p. 141.
} 
organs occurs because humans, as social beings, need help from other humans in fulfilling their daily needs. ${ }^{5}$

According to Article 1 letter e of Government Regulation Number 18 of 1981 concerning Clinical Corpse Surgery and Anatomical Corpse Surgery and Transplantation of Human Body Devices and or Tissues, organ transplantation is a series of medical actions for the transfer of human body and or tissue originating from another person's body in the context of treatment to replace tools and or body tissues that are not functioning properly.

Recently, the proliferation of buying and selling tools and body tissues in cyberspace or what is commonly called the internet has become more and more open, which was previously secret (closed) now it is like the process of buying and selling electronic goods. Based on the facts, the news provides an illustration that organ transplantation is also a bioethical problem which is also quite complicated, considering the need for human body tissue is increasing day by day, while the supply of organs is limited because some organs must be taken from the bodies of those who are dead or still alive, even though not every day. The family of the person who donated their organs gave permission for the hospital or doctor to carry out organ transplantation without an appropriate price. $^{6}$

The issuance of Regulation of the Minister of Health of the Republic of Indonesia Number 38 of 2016 concerning Organ Transplantation has at least answered questions regarding organ transplant procedures. Although previously there was also a Regulation of the Minister of Health Number 37 of 2014 concerning Determination of Death and Utilization of Donor Organs, this regulation is only specific to transplants from donors who have died, while for living donors this regulation is not stated.

Regulation of the Minister of Health of the Republic of Indonesia Number 38 of 2016 concerning Organ Transplantation provides a legal umbrella for the implementation of organ transplants that are carried out legally ${ }^{7}$. Based on Article 1 paragraph 1 of the Regulation of the Minister of Health of the Republic of Indonesia Number 38 of 2016 concerning Organ Transplantation, it is known that Organ Transplantation is the transfer of organs from a donor to a recipient for healing and restoration of the recipient's health problems. Organ transplantation is currently carried out through the National Transplant

${ }^{5}$ Iman Jauhari, Kapita Selekta Hukum Islam Jilid II, (Medan: Pustaka Bangsa Press, 2007), p. 167.

${ }^{6}$ Farid Aziz, Panduan Pelayanan Medik Model Interdisipling, (Jakarta: Buku Kedokteran EGC, 2008), p. 42.

${ }^{7}$ A Chuasanga, Ong Argo Victoria. (2019). Legal Principles Under Criminal Law in Indonesia Dan Thailand, Jurnal Daulat Hukum, Vol 2, No 1 (2019) http://jurnal.unissula.ac.id/index.php/RH/article/view/4218 
Committee which prepares policy materials, standards and guidelines for Organ Transplantation in collaboration with relevant professional organizations to be determined by the Minister, establishes an Organ Transplant information system, conducts socialization and promotion to the public to donate organs for the benefit of help and doing good deeds, organizing registration and data management of donors and recipients, and monitoring the health protection and rights of post-transplant donors.

In accordance with Article 24 Paragraph 1 Letter $d$ of the Regulation of the Minister of Health of the Republic of Indonesia Number 38 of 2016 concerning Organ Transplantation, to ensure legal certainty in organ transplantation, both donor and recipient will submit a written statement not to purchase organs from prospective donors or enter into special agreements with prospective donor, which is stated in the form of a notarial deed or a written statement legalized by a notary.

\section{Research Methods}

The approach used in this research is the approach empirical juridical, especially analyzing procedures for transplanting human organs or tissues and the role of a notary deed in organizing human organ or tissue transplants based on Minister of Health Regulation No. 38 of 2016.

The specifications in this study include descriptive analytical research. What is meant by descriptive is a complete description of valid and factual data regarding the research material. ${ }^{8}$ As for the analytical definition is to connect a data with other data that form a correlation relationship in research. ${ }^{9}$ Analytical descriptive is research that describes a valid, factual and systematic data based on the relationship of one data to another in research.

Analysis can be formulated as a process of systematic and consistent decomposition of certain phenomena. Starting from this understanding, there is a close relationship between the analytical method and the problem approach. The systematic description of the symptoms and the data obtained in this study is first presented as far as possible qualitatively. The data obtained were then analyzed qualitatively normative. This qualitative analysis was carried out descriptively and prescriptively, namely research by describing and interpreting an object according to the existing reality, without exaggerating to reveal or describe the data as it is, so as to reveal or describe reality.

\footnotetext{
${ }^{8}$ Ronny Hanitijo Soemitro, Metode Penelitian Hukum, Ghalia Indonesia, Jakarta, 1982, p. 36

${ }^{9}$ Ibid, p. 44
} 


\section{Result and Discussion}

\subsection{The Urgency of the Notary Deed of Organ Transplantation in the Context of Preventing the Sale and Purchase of Human Organs Based on the Minister of Health Regulation No. 38 of 2016}

Organ transplants are performed on organs that are legal to transplant. The problem is that based on Government Regulation No. 53 of 2021 concerning Transplantation of Organs and Body Tissues, it only contains definitions of organs and limits the purpose of transplantation (for humanitarian/non-commercial purposes), but does not set limits on which organs can and cannot be transplanted. Whereas in Article 14 of the Regulation of the Minister of Health Number 38 of 2016 concerning Organ Transplantation, limits are given to the organs that can be given by living donors, namely one kidney from both kidneys and/or part of the liver, pancreas or lungs. Organ transplants have been carried out at Dr. Kariadi at this time and there is a Transplant Team appointed by the President Director's Decree for the kidney organ. ${ }^{10}$

Parties who are allowed to donate organs, in line with Article 13 of the Minister of Health Number 38 of 2016, in principle the policy of Dr. Kariadi is that anyone can become an organ donor voluntarily without asking for anything in return. ${ }^{11}$ Donors can come from live donors or brain stem dead donors.

Based on the results of interviews with the two sources, all of the interviewees agreed that a person is not allowed to earn money from an organ transplant. In accordance with Article 3 of PP Number 53 of 2021, organ and/or tissue transplantation is carried out only for humanitarian purposes and is prohibited forcommercialized/traded under any pretext. Therefore, in the organ transplant policy at Dr. RSUP. Kariadi, in order to become an organ donor or recipient, must submit a statement stating that there is no sale and purchase of organs and/or a special agreement between the donor and recipient (especially for recipients, the statement is made in a notarial deed/notarized). ${ }^{12}$ Meanwhile, based on Notary Supriyadi ${ }^{13}$, one is not allowed to earn money from organ transplants. This is because in the notarial deed regarding organ transplantation, there is a written statement not to buy organs. Both Party I, namely patients, and party II, namely donors, with the formal contents: not buying, because the organ

\footnotetext{
${ }^{10}$ Gillan Teravosa, Interview, Junior Expert Legal Analyst/Sub. Legal and Organizational Coordinator of RSUP Dr. Kariadi Semarang, Semarang, July 16, 2021, at 10.00

${ }^{11}$ Ibid.

${ }^{12}$ Ibid.

${ }^{13}$ Notary Supriyadi, SH. MKn, Interview, Young Expert Legal Analyst/Sub. Legal and Organizational Coordinator of RSUP Dr. Kariadi Semarang, Semarang, July 16, 2021, at 10.00
} 
donation is done on the basis of humanity, not profit. The basis of donors willing to donate their organs is based on sincerity and voluntary.

Official organ transplant organizers can only be carried out in hospitals designated by the Minister of Health. As the vertical technical implementing unit of the Ministry of Health, Dr. RSUP. Kariadi is one of the hospitals in Indonesia that has been designated by the Minister of Health to carry out organ transplants. To support this, Dr. Kariadi has drawn up and stipulates the President Director's Decree on guidelines for organ transplantation and on the formation of a team for each type of organ transplant, has facilities and infrastructure that supports organ transplantation and has international accreditation. ${ }^{14}$

This is also in accordance with the answer from Notary Supriyadi who stated that the one authorized to carry out organ transplantation was the hospital appointed by the National Transplantation Committee and the deed was drawn up by the Notary. ${ }^{15}$

Organ transplantation requires legal certainty. Based on the results of interviews, legal certainty in organ transplantation, based on legislation, there should be no special agreement between the donor and the recipient, especially those that mean buying and selling or giving rewards. In accordance with article 3 paragraph (2) of PP Number 53 of 2021 it is stated that organs and/or body tissues are obtained from donors voluntarily, while in the explanation it is stated that what is meant by "voluntary" is that between the donor and recipient there is no sale-purchase agreement, other agreements, and/or requests for compensation in any form. ${ }^{16}$ This is also in accordance with the opinion of Notary Supriyadi who stated that the legal certainty of organ transplantation would be strengthened by an authentic deed, namely by a notary deed. Because the legal position in court, an authentic deed is the same as a private deed, but the legal force is higher than an authentic deed (Notary deed). The notary deed is written in full because there are comparisons, articles of agreement between the parties and the preamble, the contents of the deed containing the legal basis and the contents of the article. ${ }^{17}$

In ensuring that organ transplants are legally valid, organ transplantation at Dr. RSUP. Kariadi has been under the umbrella of the President Director's Decree regarding the implementation of organ transplantation, in which the substance of the decree refers to the prevailing laws and regulations in the field of health

\footnotetext{
${ }^{14}$ Op.Cit.

${ }^{15}$ Op.Cit.

${ }^{16}$ Op.Cit.

${ }^{17}$ Op.Cit.
} 
and organ transplantation. Meanwhile, based on the opinion of Notary Supriyadi, there must be a Legal Standing which includes: Deed/private letter, Statement and Recommendation from the Committee. There are two copies of the deed, to be given to the recipient and the donor.

All organ transplant activities at Kariadi Hospital will carry out the same procedure. The procedure is based on the President Director's Decree regarding Guidelines for Organ/Tissue Transplantation Services, medical procedures are adjusted to the transplant guidelines for each organ made by the Transplantation Team of each organ and determined by the President Director. Meanwhile, based on the opinion of Notary Supriyadi, the procedure in organ transplantation is the importance of the administrative requirements for making a notary deed, namely the original KTP of the appearers and the original Family Card and Marriage Certificate. Then the recipient (organ recipient) will look for potential donors to the committee after which the committee performs verification checks, from the committee issues a letter of recommendation, makes a statement or mutual agreement.

Based on the Regulation of the Minister of Health No. 38 of 2016, the role of the notary deed for the implementation of transplantation of human organs or tissues is to fulfill the legality and requirements to carry out a transplant in accordance with the Regulation of the Minister of Health No. 38 of 2016. In this notarial deed there must be approval from the husband and wife's family, agreement it is legally binding civil law (irrevocable). If the transplant is canceled, there will be sanctions from default for refusing or canceling based on the right to defend one's right to life.

Donation and transplantation of limbs are two factors in the transfer of tissue or organs from the body (the donor) to the recipient of the donor. Donation and transplant activities are often carried out with the aim of treating several forms of disease, including: (1). Serious treatment, if not done transplant it will result in death. Such as heart, kidney and liver transplants. (2). Treatment to avoid permanent physical defects, such as corneal transplantation, and patching a cleft lip. This type of transplant is done not to avoid death, but just a treatment to avoid lifelong disability.

Based on its demographics, the Indonesian population is mostly Muslim, so that in carrying out activities, one of which is about organ transplantation, it must also be based on Islamic law. In its development, the issue of organ transplantation has given rise to various new problems, so that it has become one of the sensitive debates in the medical and religious worlds. The occurrence of these differences and debates is due to differences in ideology, culture, and beliefs held by the community. There are some interpretations that allow donating or giving something if something to be donated belongs to him. 
Basically, the use of human organs is still a debate in Islamic law by Islamic experts in the world because some of them consider it unusual. Transplant or transplant, which is the transfer of an organ that still has a healthy life force, from a person to replace an unhealthy or malfunctioning organ belonging to another person. ${ }^{18}$ However, there are also some problems regarding transplantation, including: First, organ transplants are in good health. If the organ transplant is taken from a living and healthy person, then the law is haram. Because the act will have an effect on those who donate such as eyes or kidneys. He will face the risk and risk himself in perdition. This prohibition is like the hadith of the Prophet Muhammad ${ }^{19}$ :

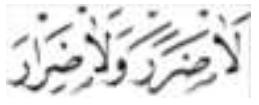

It means:

"It is not permissible to harm oneself and not to harm others" (HR. Ibn Majah)

Therefore, it is not permissible to donate body organs such as eyes, hands and feet. Because it raises a big dharar on yourself. A person should prioritize taking care of himself rather than helping others by sacrificing himself which is fatal. Second, transplant in a coma. The law is still illegal. Because this is tantamount to hastening the death of the donor. Therefore, organ transplants are not allowed. Third, transplant in a dead state. There are several conditions including: the recipient of the donor is in an emergency, which can be life-threatening, and the transplant does not result in more serious disease. ${ }^{20}$

The Second National Symposium on "organ transplantation", an agreement was signed between NU, PP Muhammadiyah and MUI on the permissibility of organ transplantation in an emergency with the aim of saving the lives of others. Other scholars such as Quraish Shihab, also allow it. According to him, the benefit of the living takes precedence. In addition, $\mathrm{K} \mathrm{H}$. 'Ali Yafie, also confirmed that there is a ushul fiqh method that can be used as a reinforcement for transplantation, namely "hurmatul hayyi a'dhamu min hurmatil mayyiti" (the honor of the living is greater than that of the dead. ${ }^{21}$ Qardawi, allows live organ transplants. He argues that although this body is a gift from God, humans are given the authority

\footnotetext{
${ }^{18}$ Hasballah Thaib dan Zamakhsyari, 20 Kasus Kedokteran Kontemporer Dalam Perspektif Islam, (Medan: Perdana Publishing, 2011), p. 87.

${ }^{19}$ Hasbi Umar, Nalar Fiqih Kontemporer (Jakarta: Gaung Persada Press, 2007, p. 180

${ }^{20}$ Masjfuk Zuhdi, Pencangkokan Organ tubuh dalam Masaail Fiqhiyah, (Jakarta: Haji Mas Agung, 1993), p.112

${ }^{21}$ Muktamar NU, Solusi Problematika Aktual hukum Islam, (Ponorogo: Panitia Muktamar NU, 1995), p.48
} 
to use and utilize it, as it is permissible to donate property. ${ }^{22}$ In essence, property belongs to Allah, but humans are given the authority to own and spend it. As Allah says in Surah an-Nūr 33:

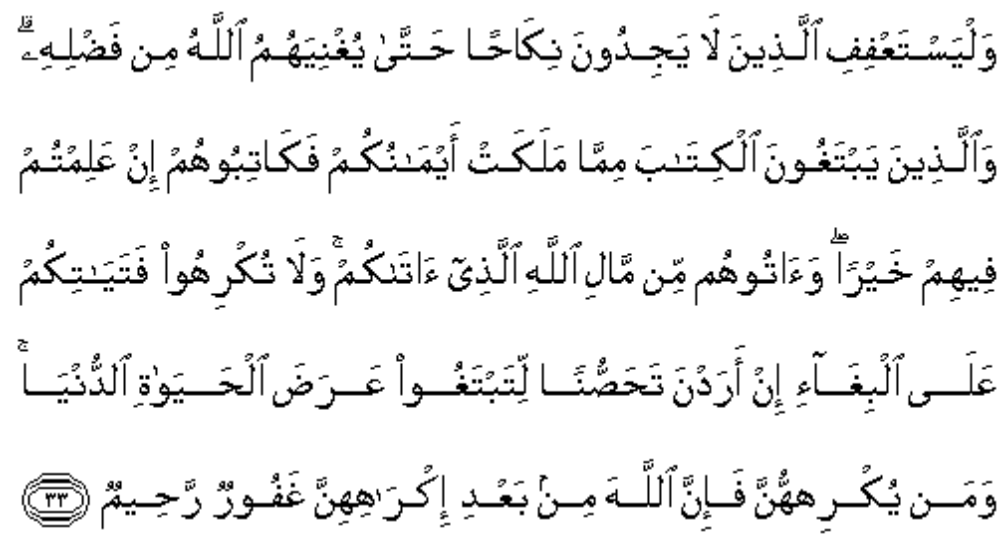

And those who are unable to marry should keep their chastity (self), so that Allah will enable them with His bounty. And the slaves you have who want a covenant, make a pact with them, if you know there is any good in them, and give them a share of the treasure God has given you. And do not force your female slaves to commit prostitution, while they themselves desire chastity, because you seek worldly gain. And whoever forces them, then indeed Allah is Forgiving, Most Merciful (to them) after they were forced.

In consideration of benefits, a person who is still alive is more entitled to use his limbs. Therefore, it is obligatory to maintain and maintain their health. For the dead, outwardly the organs of his body are no longer useful. While there are patients who are still alive, they really need it. If the transplant is not done, it will be dangerous for him. Here applies the rule "the greater benefit takes precedence over the smaller benefit". Or when there are two mudarat then it is obligatory to choose the smaller madarat". ${ }^{23}$

$$
\text { اذا ارض المفسدتان اعظمهما ا ارتكاب اخفهما }
$$

In other words, taking the organs of the dead whose organs are no longer being used has a smaller harm, compared to the harm of living people whose organs can no longer be used. The body organs for the owner are usufructuary rights (ikhtișaș). He is more entitled to his organs, but can also give or allow it to others as long as it does not damage him. In the case of organ transplantation, it can be preceded by a will witnessed by the heirs or his family, or if not, returned to the

\footnotetext{
${ }^{22}$ Yūsūf al-Qardawī, Contemporary Fatwas, (Jakarta: Gema Insani Press, Volume 2, 1995), p. 757

${ }^{23}$ Jalāl ad-Dīn Abd. Ar-Rahmān Abi Bakar as-Suyūți, al-Asybāh wa an-Naẓāir fi al-Furū' (Bairut: Dār al-Fikr, tt), p: 62.
} 
principle of prioritizing the greater benefit. ${ }^{24}$ Therefore, it is clear from the opinions of previous scholars and contemporary Muslim scientists that it is permissible to transplant human organs on the condition that it does not cause harm between parties or around the parties. The compilers made the basis of the legal decision on the permissibility of transplanting human organs from the pros and cons of various scholars. However, the only initial basis that becomes the end of this ijtihad is benefit. The authors argue that the preservation of the souls of the living takes precedence over the souls of the medically dead. Without neglecting the honor of the deceased. In this case one of the five joints of maqāșid al-syarī'ah has been successfully achieved, namely hifẓu al-nafs.

Based on positive law, namely Permenkes No. 38 of 2016 as well as Islamic law, in organ transplantation it is known that there is a condition that there is no sale and purchase of organs, there is no special agreement that provides benefits to the donor and is carried out with a notarial deed in the form of an agreement or written statement under the hand legalized or waarmerking. Whereas in Islamic law transplantation and the presence of donors are allowed in an Islamic health perspective and can be an inspiration for the community to give up their organs to be donated to those in need based on a certain agreement so that the notation deed is very important for organ transplants in the context of preventing the sale and purchase of human organs.

\subsection{Obstacles That Appear in the Making of the Notary Deed of Organ Transplant in the Context of Preventing the Sale and Purchase of Human Organs}

Based on the results of interviews with young Expert Legal Analysts/Legal and Organizational Sub-Coordinator of RSUP Dr. Kariadi Semarang and Notary Supriyadi, SH.MKn regarding obstacles that arise in the making of a notarial deed of organ transplantation in the context of preventing the sale and purchase of human organs. The informant stated that until now there are no technical or procedural obstacles in making a notarial deed of organ transplantation in the context of preventing the sale and purchase of human organs. This can happen because each prospective donor must go through a strict procedure, where if there is a suspicion it will be immediately rejected by the hospital. This advocacy team, which consists of a number of psychiatrists, will interview potential donors to identify maturity and ensure that there are no criminal offenses involved in kidney transplantation. Donors will be explored and their maturity identified with valid legal evidence. During the interview, the team will examine the donor's emotional, intellectual and cognitive abilities. The team investigated the donor's ability to make decisions for himself and ensured that he was stress-free with a review from a forensic psychiatrist professional.

${ }^{24}$ Ahmad Rofiq, Fiqh Kontekstual (Yogyakarta: Pustaka Pelajar, 2004), p. 146-148. 
However, based on the reality on the ground from the results of the research, funding in Organ Transplantation is borne by the recipient (donor recipient) so that in this case the donor recipient bears all costs incurred as in Article 39 paragraph (1) Regulation of the Minister of Health No. 38 of 2016.

Funding for Organ Transplantation at the Organ Transplant organization hospital is borne by the recipient and/or the guarantor insurance.

There are two conflicting articles regarding funding issues in Organ Transplantation raises a distinct confusion about who bears the costs funding in Organ Transplantation, so that until now it still refers to Article 39 paragraph (1) of the Regulation of the Minister of Health No. 38 of 2016 where the donor recipient bears all costs incurred.

Another obstacle that arises in the implementation of organ or human tissue transplants is that until now there are still notaries who do not know about organ donors and notary deed as authentic deeds which become the legal force of the agreement between the donor and the donor recipient on the existence of voluntary organ donors from the donor community.

\subsection{Formulation of Notary Deed in Organ or Human Tissue Transplantation Based on Minister of Health Regulation No. 38 of 2016}

The formulation of a notarial deed in the implementation of organ or human tissue transplants based on the Minister of Health Regulation No. 38 of 2016 is based on legal arrangements regarding authentic deeds, namely Article 1868 BW

An authentic deed is a deed which, in the form determined by law, is made by or before public officials in power for that purpose where the deed is made.

The structure of articles 38-52 UUJN includes

(1) Head/Beginning of Deed

(2) Comparison

(3) Facing Capacity

(4) Premise

(5) Contents/Body of Deed

(6) End of Deed 
The writing of this notarial deed is in the form of written statement of no sale and purchase of organs with two copies to be given to recipients and donors. The formulation of the notarial deed in the implementation of human organ or tissue transplants based on the Minister of Health Regulation No. 38 of 2016 is as follows:

\section{Closing}

Based on positive law, namely Permenkes No. 38 of 2016 as well as Islamic law, in organ transplantation it is known that there is a condition that there is no sale and purchase of organs, there is no special agreement that provides benefits to the donor and is carried out with a notarial deed in the form of an agreement or written statement under the hand. legalized or waarmerking. Whereas in Islamic law transplantation and the presence of donors are allowed in an Islamic health perspective and can be an inspiration for the community to give up their organs to be donated to those in need based on a certain agreement so that the notation deed is very important for organ transplants in the context of preventing the sale and purchase of human organs. Currently, there are no technical or procedural obstacles in making a notarial deed of organ transplantation in the context of preventing the sale and purchase of human organs. This can happen because each prospective donor must go through a strict procedure, where if there is a suspicion it will be immediately rejected by the hospital. After passing through the stages of strict inspection then an organ donor agreement will be made before a notary for the legitimacy of the organ transplant process. After that, the team will check the donor's health condition so that it can be ascertained that the donor who has arrived on the operating table means that no previous problems have been found. Problems in organ transplantation often exist in funding problems where in article 38 of the Minister of Health No. 38 of 2016 it is stated that: The Central Government and Regional Governments are responsible for funding the implementation of Organ Transplants through the APBN and APBD, while Article 39 paragraph (1) Permenkes No. 38 of 2016, funding in Organ Transplantation is borne by the recipient (donor recipient). Besides that, there are still a notary who does not know about organ donors and a notary deed as an authentic deed which becomes the legal force of the agreement between the donor and the donor recipient on the existence of organ donation which is carried out voluntarily from the donor to the donor recipient. The formulation of a notarial deed in the implementation of human organ or tissue transplants based on the Minister of Health Regulation No. 38 of 2016 is based on the legal arrangement regarding authentic deeds, namely Article 1868 BW. The structure of the deed Article 38-52 of the UUJN includes the Head/Beginning of the Deed, Comparison, Appearing Capacity, Premise, Content/Body of the Deed, End of the Deed. The writing of 
this notarial deed is in the form of written statement of no sale and purchase of organs with two copies to be given to recipients and donors.

\section{References}

Al-Qur'an and Hadits

Journals:

[1] A Chuasanga, Ong Argo Victoria. (2019). Legal Principles Under Criminal Law in Indonesia Dan Thailand, Jurnal Daulat Hukum, Vol 2, No 1 (2019) http://jurnal.unissula.ac.id/index.php/RH/article/view/4218

[2] Mashdurohatun, A, Risdawati, I., Sucipto, H. 2020. Protection of Doctors and Patients in Implementing Informed Consent Based on Justice Value, Journal of Talent Development and Excellence. Special Issue Vol 12 No 2s.

[3] Wahyuningsih, S.E., Hanapiah, Y. 2018. Hal-Hal yang Perlu Diperhatikan Notaris dalam Membuat Akta Perjanjian Notariil. Jurnal Akta Vol 5 No 1.

Books:

[1] Aziz, Farid. 2008. Panduan Pelayanan Medik Model Interdisipling, Jakarta: Buku Kedokteran EGC.

[2] Dewi, Alexandra Indriyati. 2008. Etika dan Hukum Kesehatan, Yogyakarta: Pustaka Book Publisher.

[3] Hadjon, Philipus M. 1987. Perlindungan Hukum Bagi Rakyat-Sebuah Studi Tentang Prinsip- prinsipnya, Penanganannya Oleh Pengadilan Dalam Lingkungan Peradilan Umum Dan Pembentukan Peradilan Administrasi Negara, Surabaya: Bina IImu.

[4] Jauhari, Iman. 2007. Kapita Selekta Hukum Islam Jilid II, Medan: Pustaka Bangsa Press.

[5] Komalawati, Veronika. 2002. Peran Inform Consent Dalam Transaksi Terapiutik (Persetujuan Dalam Hubungan Dokter dan Pasien) Suatu Tinjauan Yuridis, Bandung: Citra Aditya Bakti.

[6] Locke, John. 1964. The Second Treatise of Civil Government and a Letter Concerning Toleration, Oxford: Oxford University.

[7] Nasution, Bander Jonathan. 2005. Hukum Kesehatan: Pertanggungjawaban Dokter, (Jakarta: Rineka Cipta.

[8] Notohamidjojo, O. 1970. Makna Negara Hukum, (Jakarta: Badan Penerbit Kristen.

[9] Priyono, Erry Agus. 2003. Materi Perkuliahan Matakuliah Metodologi Penelitian Hukum, Semarang:UNDIP

[10] Smith, Rhona K.M. 2008. Hukum Hak Asasi Manusia, Yogyakarta: Pusham UII. 
[11] Soekanto, Soerjono. 1982. Pengantar Penelitian Hukum. Jakarta : UI Press.

[12] Sulistyowati \& Sidarta. 2009. Metodologi Penelitin Hukum Konstelasi dan Refleksi, Buku Obor, Jakarta

[13] Tanya, Bernard L. Yoan N. Simanjuntak, dan Markus Y. Hage. 2010. Teori Hukum, (Yogyakarta: Genta Publishing.

[14] Yamin, Muhammad. 1982. Proklamasi dan Konstitusi Republik Indonseia, (Jakarta: Ghalia Indonesia.

[15] Zuhdi, Masjfuk. 1993. Pencangkokan Organ tubuh dalam Masaail Fiqhiyah, (Jakarta: Haji Mas Agung)

Regulations:

[1] Act No. 2 of 2014 concerning Amendments to Act No. 30 of 2004 concerning the Position of Notary

[2] Act No. 36 of 2009 concerning Health

[3] Act No. 39 of 1999 concerning Human Rights

[4] Code of Civil law

[5] Constitution of the Republic of Indonesia 1945

[6] Government Regulation No. 18 of 1981 concerning Clinical Corpse Surgery and Anatomical Corpse Surgery and Transplantation of Human Body Devices or Tissues

[7] Minister of Health Regulation Number 37 of 2014 concerning Determination of Death and Utilization of Donor Organs

[8] Regulation of the Minister of Health of the Republic of Indonesia Number 38 of 2016 concerning Organ Transplantation 